\title{
PECTINASE AND POLYGALACTURONASE PRODUCTION BY A THERMOPHILIC ASPERGILLUS FUMIGATUS ISOLATED FROM DECOMPOSTING ORANGE PEELS
}

\author{
Urmila Phutela; Vikram Dhuna; Shobhna Sandhu; B.S. Chadha*
}

Department of Microbiology, Guru Nanak Dev University, Amritsar, Punjab, India

Submitted: March 03, 2004; Returned to authors for corrections: July 07, 2004; Approved: March 28, 2005

\begin{abstract}
A thermophilic fungal strain producing both pectinase and polygalacturonase was isolated after primary screening of 120 different isolates. The fungus was identified as Aspergillus fumigatus Fres. MTCC 4163. Using solid-state cultivation, the optimum levels of variables for pectinase and polygalacturonase (PG) production were determined. Maximal levels of enzyme activities were achieved upon growing the culture in a medium containing wheat bran, sucrose, yeast extract and $\left(\mathrm{NH}_{4}\right)_{2} \mathrm{SO}_{4}$ after 2-3 days of incubation at a temperature of $50^{\circ} \mathrm{C}$. Highest enzyme activities of $1116 \mathrm{Ug}^{-1}$ for pectinase and $1270 \mathrm{Ug}^{-1}$ for polygalacturonase were obtained at $\mathrm{pH} 4.0$ and 5.0, respectively.
\end{abstract}

Key words: thermophilic fungi, Aspergillus fumigatus, pectinase, polygalacturonase

\section{INTRODUCTION}

Pectinolytic enzymes catalyzing the degradation of pectic substances are of great industrial importance (28). The pectinases are required for extraction and clarification of fruit juices and wines, extraction of oils, flavors and pigments from plant materials, preparation of cellulose fibers for linen, jute and hemp manufacture (8), coffee and tea fermentations (29) and novel applications in the production of oligogalacturonides as functional food components (13). Fungal polygalacturonases used in industrial processes for juice clarification are mainly obtained from mesophilic aspergilli and penicillia (3) and the range of enzyme sources is being extended through new recombinant and non-recombinant fungal strains. Thermophilic fungi are potential sources of various industrially important thermostable enzymes, such as lipases, xylanases, proteases, amylases and pectinases. These enzymes have numerous applications in the detergent, starch, food, paper and pharmaceutical industries (17).

Higher cost of the production is perhaps the major constraint in commercialization of new sources of enzymes. Though, using high yielding strains, optimal fermentation conditions and efficient enzyme recovery procedures can reduce the cost. In addition, technical constraint includes supply of cheap and pure raw materials and difficulties in achieving high operational stabilities, particularly to temperature and $\mathrm{pH}$. Therefore, the understanding of various physiological and genetic aspects of pectinase is required for producing thermostable and acid stable strains of pectinolytic fungi.

Literature highlighting the optimization, biochemical characterization, genetics and strain improvement studies of pectinases from mesophilic fungi $(7,11,18,19)$ is available. However, the studies on pectinases from thermophilic fungi are lacking. Considering the biotechnological importance of thermophilic fungi in the enzyme industry, the present paper reports the isolation of pectin degrading thermophilic fungi from various sources, their screening and process evaluation.

\section{MATERIALS AND METHODS}

\section{Isolation of thermophilic fungi}

Thermophilic fungi were isolated from different soil samples, compost and decomposed matter collected from the vegetable, fruit markets and composting soils of Amritsar, Jalandhar,

*Corresponding Author. Mailing address: Department of Microbiology, Guru Nanak Dev University, Amritsar, Punjab, 143005, India. Tel.: (+91183) 225-8802 Extn. 3317, Fax: (+91183) 225-8820. E-mail: chadhabs@yahoo.com 
Ludhiana, and Gurdaspur cities of Punjab (India). Isolation medium of following composition, $\mathrm{gL}^{-1}$ (pectin, 10.0; sucrose, 10.0; tryptone, 3.0; yeast extract, $2.0 ; \mathrm{KCl}, 0.5 ; \mathrm{MgSO}_{4} .7 \mathrm{H}_{2} \mathrm{O}$, $\left.0.5 ; \mathrm{MnSO}_{4} .5 \mathrm{H}_{2} \mathrm{O}, 0.01 ;\left(\mathrm{NH}_{4}\right)_{2} \mathrm{SO}_{4}, 2.0\right)$ supplemented with mineral salt solution of composition $\mathrm{g} / 100 \mathrm{~mL}\left(\mathrm{CuSO}_{4} .5 \mathrm{H}_{2} \mathrm{O}\right.$, $0.04 ; \mathrm{FeSO}_{4}, 0.08 ; \mathrm{Na}_{2} \mathrm{MoO}_{4}, 0.08 ; \mathrm{ZnSO}_{4}, 0.8 ; \mathrm{Na}_{2} \mathrm{~B}_{4} \mathrm{O}_{7}, 0.004$, $\left.\mathrm{MnSO}_{4}, 0.008\right), 1 \mathrm{~mL}$; distilled water to make 1L solution; $\mathrm{pH}$ 5.5-6.0 was used (27). To the above medium, ampicillin (100 mg/ $\mathrm{mL}$ ) was added to restrict bacterial growth. The inoculated plates were incubated at $50^{\circ} \mathrm{C}$ for 5-7 days. The cultures were further purified by sub culturing on YPSS (Yeast soluble starch agar) medium having composition, $\mathrm{gL}^{-1}$ (starch, 15; yeast extract, 0.4; $\mathrm{K}_{2} \mathrm{HPO}_{4}, 0.23 ; \mathrm{KH}_{2} \mathrm{PO}_{4}, 0.2 ; \mathrm{MgSO}_{4} .7 \mathrm{H}_{2} \mathrm{O}, 0.05$; citric acid, 0.052 ; pH 5.5-6.0).

\section{Screening of thermophilic fungal isolates for pectinolytic activity}

Preliminary screening of isolates for pectinase production was carried out by disc plate method of Acuna-Arguelles et al. (2). The size of clearance zone formed around the colonies using $1 \%$ cetrimide solution corresponds to the enzymatic activity of a particular culture. The potency index of each isolate was calculated as the ratio of zone diameter to colony diameter. The cultures showing high potency index were further screened by semiquantitative plate assay method $(22,23)$. The cultures were individually plated on YPSS medium (9) containing pectin in place of starch and incubated at $50^{\circ} \mathrm{C}$. A $6 \mathrm{~mm}$ colony from the growing edge of the colony was transferred to $2 \mathrm{~mL}$ citrate buffer (0.1M; pH 4.0), incubated for $1 \mathrm{~h}$ at $50^{\circ} \mathrm{C}$ under shaking conditions. The resultant extract was assayed for pectinase activity. The released sugars were estimated using DNS. On the basis of plate assay, eight cultures were selected for further studies and were compared along with three standard cultures for pectinase production by solid state culturing. The solidstate cultivation was carried out using basal medium of following composition (1), given as $\mathrm{gL}^{-1}$ : (pectin, 10; urea, 3.0; sucrose, 31.4; $\left(\mathrm{NH}_{4}\right)_{2} \mathrm{SO}_{4}, 12.6 ; \mathrm{KH}_{2} \mathrm{PO}_{4}, 6.5 ; \mathrm{FeSO}_{4}, 0.29$; sugarcane bagasse, $231.0 ; \mathrm{pH}, 5.0-5.5$. The final moisture was adjusted to $70 \%$. The flasks were inoculated with spore suspension $(1 \mathrm{~mL})$ containing $\left(10^{6}\right.$ spores $\left.\mathrm{mL}^{-1}\right)$ and incubated at $50^{\circ} \mathrm{C}$ for $2-3$ days. The crude enzyme was extracted by adding $100 \mathrm{~mL}$ of citrate buffer (0.05M; pH 5.5) to each flask followed by filtration and centrifugation at $14400 \mathrm{~g}$. The resultant extract was used for enzyme assay.

The isolate TF3, identified as Aspergillus fumigatus Fres. MTCC 4163 by Microbial Type Culture Collection (MTCC), Chandigarh, India, was taken up for further studies.

\section{Production studies}

The production of the pectinase was followed for 5 days; the contents of the flasks were harvested at regular intervals (24h) by adding $100 \mathrm{ml}$ citrate buffer $(50 \mathrm{mM}$, pH 5.0) followed by centrifugation. The resultant clear extract was assayed for pectinase and $\mathrm{PG}$ activities.

\section{Effect of physico-chemical parameters}

The effect of natural substrates like different complex carbon source (malt sprouts, wheat bran, rice bran and pectin from pomegranate, lemon, banana, orange and mussami) and purified commercial carbon sources (glucose, sucrose, galactose, trehalose, carboxymethyl cellulose and starch), nitrogen sources urea and $\left(\mathrm{NH}_{4}\right)_{2} \mathrm{SO}_{4}(\mathrm{U}+\mathrm{N})$, yeast extract and $\left(\mathrm{NH}_{4}\right)_{2} \mathrm{SO}_{4}(\mathrm{Y}+\mathrm{N})$, peptone and $\left(\mathrm{NH}_{4}\right)_{2} \mathrm{SO}_{4}(\mathrm{P}+\mathrm{N})$, soybean meal and $\left(\mathrm{NH}_{4}\right)_{2} \mathrm{SO}_{4}$ $(\mathrm{So}+\mathrm{N})$, malt sprouts and $\left(\mathrm{NH}_{4}\right)_{2} \mathrm{SO}_{4}(\mathrm{M}+\mathrm{N})$, yeast extract and $\mathrm{NaNO}_{3}(\mathrm{Y}+\mathrm{S})$, peptone and $\mathrm{NaNO}_{3}(\mathrm{P}+\mathrm{S})$, urea and $\mathrm{NaNO}_{3}(\mathrm{U}+\mathrm{S})$, incubation temperature between 30 and $80^{\circ} \mathrm{C}$ and effect of $\mathrm{pH}$ on pectinase and PG production were studied.

\section{Analytical procedure}

The pectinase and $\mathrm{PG}$ activities were determined using pectin and polygalactouronic acid as substrates (20). The reaction mixture $(1 \mathrm{~mL})$ containing equal amounts of substrate $(1 \%)$ prepared in citrate buffer $(0.05 \mathrm{M} \mathrm{pH} 4.4)$ and suitably diluted enzyme was incubated at $50^{\circ} \mathrm{C}$ for 30 minutes in water bath. After incubation $3 \mathrm{~mL}$ DNS solution was added to stop the reaction and tubes were kept in boiling water for 10 minutes. On cooling, the developed colour was read at $575 \mathrm{~nm}$ using UVvisible spectrophotometer (Shimadzu-Mini 1240). The amount of released reducing sugar was quantified using galactouronic acid as standard. The enzyme activity was calculated as the amount of enzyme required to release one micromole equivalent of galactouronic acid per minute under assay condition. The activities expressed as units/g of substrate. The protein in the supernatant was measured by the method of Lowry et al. (16)

\section{Effect of $\mathrm{pH}$ and temperature on enzyme activities}

The enzyme extract was pre-incubated at different temperatures ranging from $30-80^{\circ} \mathrm{C}$ for different time intervals and then assayed for pectinase and PG activity. The effect of $\mathrm{pH}$ on pectinase and $\mathrm{PG}$ activities were studied between $\mathrm{pH} 3.0$ - 9.0 using citrate/phosphate $(\mathrm{pH} 3.0-7.2)$ and Tris- $\mathrm{HCl}(\mathrm{pH} 7.2-$ 9.0) buffers $(50 \mathrm{mM})$. All the experiments were conducted in triplicate and the results show the mean values of the activities.

\section{RESULTS}

\section{Screening of isolates}

Thermophilic fungal strains isolated from various sources and sites of different cities of Punjab, were purified and their cultural and morphological characteristics were examined (9). Fungal cultures were further screened by disc plate method and the potency index was calculated. Fifteen cultures had a potency index above 3.5, thirty-five cultures had potency index between 3.0-3.5, and forty-three isolates had a potency index of 
2.0-3.0. These isolates were categorized as high, moderate and low pectinase producers, respectively.

High pectinase producing strains were further screened semiquantitatively by plate assay method. Results in Fig. 1 shows that the maximal pectinolytic activity was observed in isolate TF3 (O.D.value-0.978) closely followed by V50 (0.957) and V47 $(0.802)$. Minimum enzyme activity was observed in TF40 (0.126). Eight isolates namely, TF3, V7, V44, V45, V47, V50, V52, V53 and three standard cultures Thermoascus aurantiacus 204492, T. aurantiacus 216529 and Myceliophthora sp. were further screened by solid state fermentation. The results shown in Fig. 2 indicate that isolate TF3 produced high pectinase 234 $\mathrm{Ug}^{-1}$ and PG $207 \mathrm{Ug}^{-1}$ activities, followed by V7 producing 203 $\mathrm{Ug}^{-1}$ and $121 \mathrm{Ug}^{-1}$ of pectinase and PG activities, respectively. Maximum protein concentration of $0.59 \mathrm{mg} \mathrm{g}^{-1}$ of substrate was produced in isolate TF3, followed by V44 $\left(0.48 \mathrm{mg} \mathrm{g}^{-1}\right)$. On the basis of these screening experiments, the isolate TF3 was found to be a potential source of pectinolytic enzymes. The isolate was identified as Aspergillus fumigatus Fres. MTCC 4163. This culture was used for optimization of pectinase production using solid substrate culturing.

\section{Production of pectinase and PG by A. fumigatus}

The production profile of pectinase and $\mathrm{PG}$ on pectin containing basal medium without sucrose was studied (Fig. 3). It was found that maximal production of pectinase $\left(415 \mathrm{Ug}^{-1}\right)$ and PG $\left(473 \mathrm{Ug}^{-1}\right)$ was obtained after 48 and $72 \mathrm{~h}$ of incubation, respectively. Further incubation resulted in the decline in enzyme activities up to $120 \mathrm{~h}$.

\section{Effect of substrate}

The commercial pectin in the production medium was replaced with equal amounts of different natural substrates,

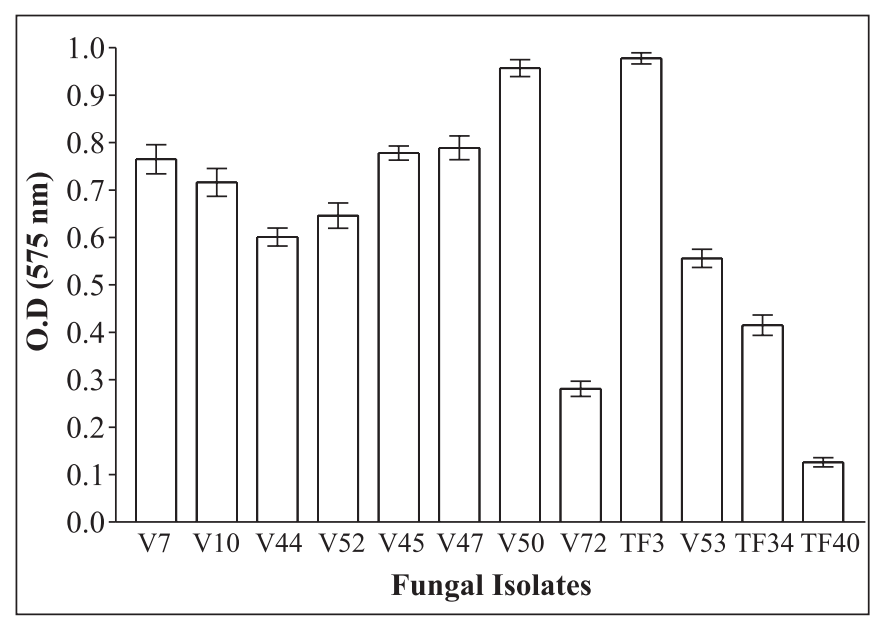

Figure 1. Semiquantitative analysis of thermophilic fungal isolates for pectinase production.

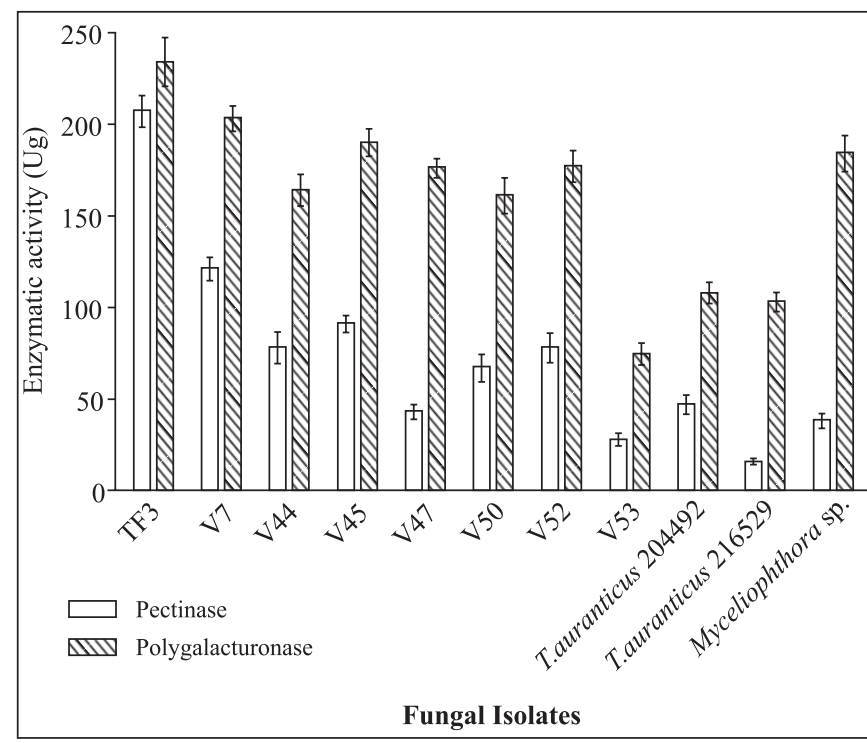

Figure 2. Screening of thermophilic fungal isolates by solid state culturing.

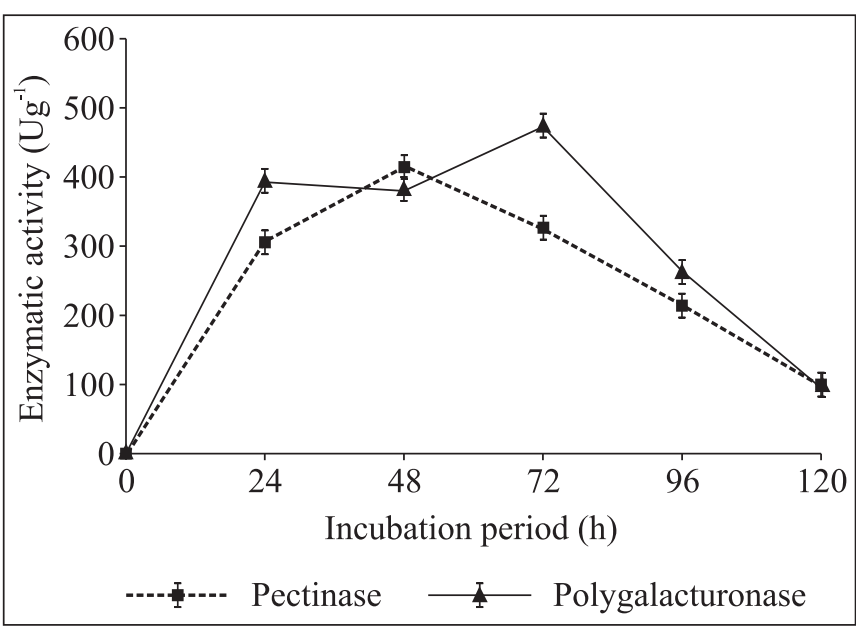

Figure 3. Enzymatic profile of Aspergillus fumigatus Fres. by solid state culturing.

i.e., malt sprouts, wheat bran, rice bran, pomegranate pectin, lemon pectin, banana pectin, orange pectin and Citrus sinensis (Var. Mussami) pectin. The results (Table 1) show that wheat bran supported maximum pectinase production $\left(589 \mathrm{Ug}^{-1}\right)$ and was closely followed by commercial pectin $\left(569 \mathrm{Ug}^{-1}\right)$. The PG activity however was maximally supported by pure pectin (642 $\left.\mathrm{Ug}^{-1}\right)$ followed by wheat bran $\left(625 \mathrm{Ug}^{-1}\right)$. The minimum activity of $264 \mathrm{Ug}^{-1}$ of pectinase and $283 \mathrm{Ug}^{-1}$ of polygalacturonase was observed in Citrus sinensis (Var. Mussami) pectin. 
Table 1. Effect of natural substates on pectinolytic enzyme production of Aspergillus fumigatus Fres.

\begin{tabular}{lcc}
\hline $\begin{array}{c}\text { Natural } \\
\text { Substrates }\end{array}$ & $\begin{array}{c}\text { Pectinase } \\
\text { activity }\left(\mathrm{Ug}^{-1}\right)\end{array}$ & $\begin{array}{c}\text { Polygalacturonase } \\
\text { activity }\left(\mathrm{Ug}^{-1}\right)\end{array}$ \\
\hline Pure pectin & $569.0 \pm 35$ & $642.0 \pm 28$ \\
Malt sprout & $452.0 \pm 40$ & $455.0 \pm 31$ \\
Wheat Bran & $589.0 \pm 36$ & $625.0 \pm 33$ \\
Rice Bran & $452.0 \pm 30$ & $489.0 \pm 29$ \\
Pomegranate & $437.0 \pm 26$ & $474.0 \pm 25$ \\
Lemon & $408.0 \pm 29$ & $401.0 \pm 24$ \\
Banana & $361.0 \pm 25$ & $387.0 \pm 35$ \\
Orange & $363.0 \pm 21$ & $299.0 \pm 40$ \\
Citrus sinensis & $264.0 \pm 13$ & $283.0 \pm 23$ \\
\hline
\end{tabular}

S.E at $5 \%$ level.

\section{Effect of supplementation of synthetic carbon sources}

Addition of different carbon sources (glucose, trehalose, sucrose, galactose, carboxy methylcellulose (CMC) and starch to wheat bran containing production medium, on the pectinase production was studied. The supplementation of sucrose to the production medium resulted in marked increase in pectinolytic activities producing $792 \mathrm{Ug}^{-1}$ of pectinase and 868 $\mathrm{Ug}^{-1}$ of polygalacturonase as compared to control, which produced 575 and $605 \mathrm{Ug}^{-1}$ of pectinase and polygalacturonase, respectively. The enzyme production however was strongly repressed in the presence of glucose, showing only $124 \mathrm{Ug}^{-1}$ and $136 \mathrm{Ug}^{-1}$ of pectinase and polygalacturonase activities, respectively (Table 2).

\section{Effect of nitrogen sources}

Of the various nitrogen sources used in the medium (Table 3 ), the presence of yeast extract+ $\left(\mathrm{NH}_{4}\right)_{2} \mathrm{SO}_{4}$ was found to support maximal production of pectinase $\left(925 \mathrm{Ug}^{-1}\right)$ followed by malt sprouts $+\left(\mathrm{NH}_{4}\right)_{2} \mathrm{SO}_{4}\left(785 \mathrm{Ug}^{-1}\right)$, which also supported maximal $\mathrm{PG}$ activity $\left(938 \mathrm{Ug}^{-1}\right)$.

\section{Effect of temperature}

The results in Fig. 4 showed that the flasks containing basal medium with wheat bran, sucrose and yeast extract $+\left(\mathrm{NH}_{4}\right)_{2} \mathrm{SO}_{4}$ supported maximal pectinase $\left(972 \mathrm{Ug}^{-1}\right)$ and $\mathrm{PG}\left(1023 \mathrm{Ug}^{-1}\right)$ activities at $50^{\circ} \mathrm{C}$. The production of these enzymes however, was drastically affected at incubation temperatures of 35 or $55^{\circ} \mathrm{C}$.

\section{Effect of assay temperature on pectinase activity}

The results (Fig. 5) showed that assay temperature of $50^{\circ} \mathrm{C}$ for $10 \mathrm{~min}$ was most suitable for maximum pectinase activity $\left(1071 \mathrm{Ug}^{-1}\right)$ followed by $60^{\circ} \mathrm{C}\left(925 \mathrm{Ug}^{-1}\right)$. With the increase in incubation period, a constant decrease in enzyme activity was observed at their respective temperatures. At 60 min incubation
Table 2. Effect of synthetic carbon sources on pectinolytic enzyme production of Aspergillus fumigatus Fres.

\begin{tabular}{lcc}
\hline $\begin{array}{c}\text { Synthetic } \\
\text { carbon sources }\end{array}$ & $\begin{array}{c}\text { Pectinase } \\
\text { activity }\left(\mathrm{Ug}^{-1}\right)\end{array}$ & $\begin{array}{c}\text { Polygalacturonase } \\
\text { activity }\left(\mathrm{Ug}^{-1}\right)\end{array}$ \\
\hline Control & $575.0 \pm 21$ & $605.0 \pm 28$ \\
Trehalose & $467.0 \pm 13$ & $657.0 \pm 32$ \\
Sucrose & $792.0 \pm 47$ & $868.0 \pm 39$ \\
Galactose & $631.0 \pm 16$ & $554.0 \pm 24$ \\
CMC & $306.0 \pm 19$ & $372.0 \pm 15$ \\
Starch & $386.0 \pm 27$ & $415.0 \pm 21$ \\
Glucose & $124.0 \pm 12$ & $136.0 \pm 9$ \\
\hline
\end{tabular}

S.E at $5 \%$ level.

Table 3. Effect of Nitrogen sources on pectinolytic enzyme production of Aspergillus fumigatus Fres.

\begin{tabular}{ccc}
\hline $\begin{array}{c}\text { Nitrogen } \\
\text { sources }\end{array}$ & $\begin{array}{c}\text { Pectinase } \\
\text { activity }\left(\mathrm{Ug}^{-1}\right)\end{array}$ & $\begin{array}{c}\text { Polygalacturonase } \\
\text { activity }\left(\mathrm{Ug}^{-1}\right)\end{array}$ \\
\hline U+N & $467.0 \pm 27$ & $683.0 \pm 37$ \\
Y+N & $925.0 \pm 10$ & $865.0 \pm 21$ \\
P+N & $419.0 \pm 19$ & $613.0 \pm 23$ \\
So+N & $408.0 \pm 22$ & $372.0 \pm 18$ \\
M+N & $785.0 \pm 16$ & $938.0 \pm 58$ \\
Y+S & $372.0 \pm 15$ & $511.0 \pm 18$ \\
P+S & $452.0 \pm 26$ & $485.0 \pm 26$ \\
U+S & $350.0 \pm 22$ & $346.0 \pm 20$ \\
\hline
\end{tabular}

S.E at $5 \%$ level.

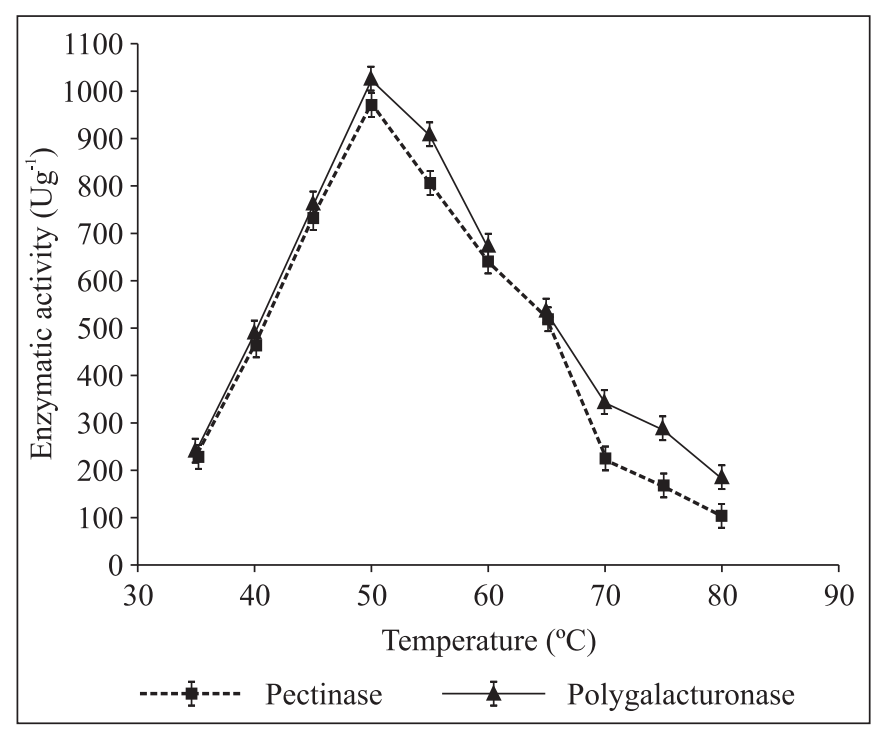

Figure 4. Effect of incubation temperature on pectinolytic enzyme production of Aspergillus fumigatus Fres. 
only $20 \%$ activity was quantified. But with the increase in temperature the decrease was not much pronounced. This is evident from the fact that incubating the enzyme at $80^{\circ} \mathrm{C}$ for 10 min resulted in only $25 \%$ loss of activity. These results clearly indicate that pectinase complex of this fungus is catalytically active with high rate of reaction at elevated temperatures. Similar profiles were obtained for PG where maximum activity (1122 $\mathrm{Ug}^{-1}$ ) was obtained at assay temperature of $50^{\circ} \mathrm{C}$ after 10 minutes of incubation, the PG activity declined upon prolonged incubation.

\section{Effect of pH}

Results shown in Fig. 6 indicated that $\mathrm{pH} 4.0$ was more suitable for pectinase (1116 Ug-1) activity while $\mathrm{PG}$ was active

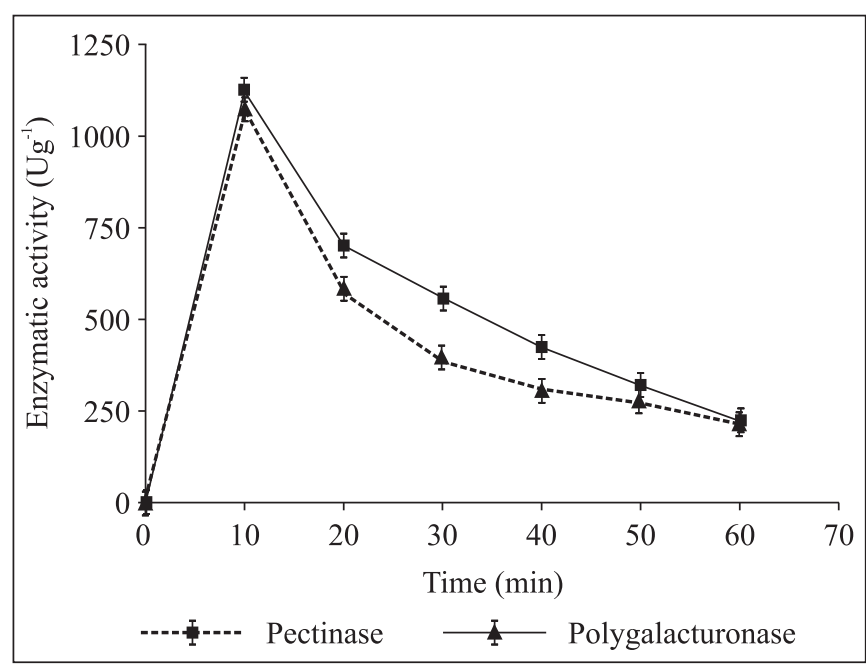

Figure 5. Effect of assay temparature $\left(\mathrm{T}=50^{\circ} \mathrm{C}\right)$ on pectinase and $\mathrm{PG}$ activity of Aspergillus fumigatus Fres.

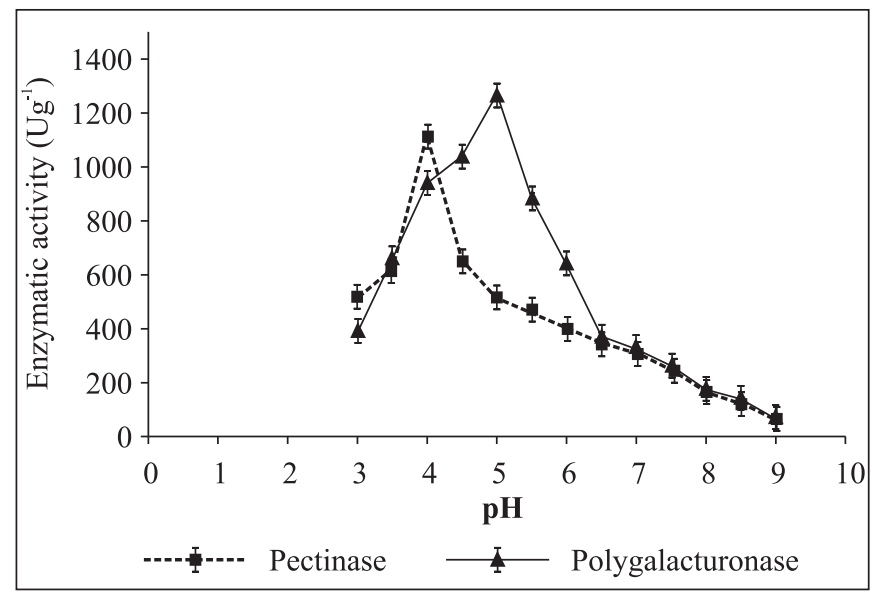

Figure 6. Effect of $\mathrm{pH}$ on pectinase activity of Aspergillus fumigatus Fres. at $\mathrm{pH} 5.0(1270 \mathrm{Ug}-1)$. Either increase or decrease in $\mathrm{pH}$ beyond the optimum value showed decline in enzyme activities.

From the above experiments it was concluded that the thermophilic fungi $A$. fumigatus Fres. expressed maximum pectinolytic activities after 2-3 days of incubation in a medium containing wheat bran, sucrose, yeast extract and $\left(\mathrm{NH}_{4}\right)_{2} \mathrm{SO}_{4}$ at $50^{\circ} \mathrm{C}$. The enzyme was acid active and moderately thermostable.

\section{DISCUSSION}

There are very few reports available on thermostable acid active pectinase production by thermophilic fungi. This study reports the isolation and screening of pectinolytic thermophilic fungi. Using semi-quantitative plate assay approach, a thermophilic fungal strain TF3 (Aspergillus fumigatus MTCC 4163) isolated from decomposing orange peel waste, was selected as the best producer of pectinase and PG. The plate assay approach has been previously employed in our lab for isolating hyper amylase producing mutants/fusants of thermophilic fungus Thermomyces lanuginosus $(22,23)$.

The incubation period to achieve peak pectinase activity by the isolate TF3 was 2 days, which is suitable from the commercial viewpoint. Earlier, Said et al. (24) have reported maximum pectinase activity in Penicillium frequentans after culturing for $48 \mathrm{~h}$, whereas polygalacturonase activity was maximum on third day of incubation as reported by Hart et al. (14) and Crotti et al. (10) in Rhizopus oryzae and Neurospora crassa, respectively.

The pectinase production by A. fumigatus TF3 was ably supported by wheat bran, which is a cheap and readily available carbon source, similar findings were reported by Fujio et al. (12) in Rhizopus sp. When supplemented with sucrose the enzyme production was enhanced and this is in accordance with similar observations made by Crotti et al. (10), BaracatPereira et al. (6) and Minussi et al. (21).

The supplementation of yeast extract $+\left(\mathrm{NH}_{4}\right)_{2} \mathrm{SO}_{4}$ followed by malt sprouts $+\left(\mathrm{NH}_{4}\right)_{2} \mathrm{SO}_{4}$ greatly enhanced the enzyme production and promoted more than twice the enzyme activity as compared to Urea+ $\mathrm{NaNO}_{3}$, in the present study. Our results are in concurrence with the observations of Sapunova (25) who also found that malt sprouts and ammonium salts stimulated the pectinolytic enzyme production in A. alliaceus BIM-83. Moreover, Sapunova et al. (26) has also observed that $\left(\mathrm{NH}_{4}\right)_{2} \mathrm{SO}_{4}$ stimulated pectinase synthesis, as in its absence fungus displayed a slight proteolytic activity and did not produce extracellular pectinases. Report of Aguilar et al. (4) showed yeast extract as the best inducer of exopectinases in Aspergillus sp. The strain A. fumigatus TF3 was able to grow optimally at $50^{\circ} \mathrm{C}$ and also produced maximum amount of pectinase at $50^{\circ} \mathrm{C}$. Thermophilic fungi have been reported to optimally produce enzymes at $50^{\circ} \mathrm{C}(22,23)$. Loudiere et al., (15) reported higher temperatures for optimum activity, $50-60^{\circ} \mathrm{C}$ for 
polygalacturonase in A. wentii when grown on sugar beet pulp. An acidic $\mathrm{pH}$ of 4.0-5.0 was found to support high pectinase and PG activities. Alana et al. (5) also reported low $\mathrm{pH}$ values in $P$. italicum for obtaining high pectinase production. The study has highlighted that the novel A. fumigatus isolate is a good source for producing pectinases on cheap carbon source in short incubation period during solid-state cultivation. The produced pectinases are catalytically active at high temperatures and low $\mathrm{pH}$. Further work on purification and characterization of pectinase from A. fumigatus TF3 is currently in progress.

\section{ACKNOWLEDGEMENT}

This work was supported by a research grant from the University Grants Commission (UGC), New Delhi, India. One of the authors, Vikram Dhuna, is a recipient of junior research fellowship from UGC, India.

\section{RESUMO}

\section{Produção de pectinases e poligalacturonase por Aspergillus fumigatus termofílico isolado de cascas de laranja em decomposição}

Através da tiragem de 120 cepas de fungos, isolou-se uma cepa capaz de produzir tanto pectinase quanto poligalacturonase. A cepa foi identificada como Aspergillus fumigatus Fres. MTCC 4163. Empregando cultivo em estado sólido, determinou-se os níveis ótimos das variáveis para a produção de pectinase e de poligalacturonase. Os níveis máximos de atividade enzimática foram obtidos quando a cultura era realizada em meio contendo farelo de trigo, sacarose, extrato de levedura e $\left(\mathrm{NH}_{4}\right)_{2} \mathrm{SO}_{4}$ por 23 dias a uma temperatura de $50^{\circ} \mathrm{C}$. A atividade máxima de pectinase $\left(1116 \mathrm{Ug}^{-1}\right)$ e de poligalacturonase $\left(1270 \mathrm{Ug}^{-1}\right)$ foi obtida em $\mathrm{pH}$ 4,0 e 5,0 , respectivamente.

Palavras-chave: fungos termofílicos, Aspergillus fumigatus, pectinase, poligalacturonase

\section{REFERENCES}

1. Acuna-Argulles, M.; Gutierez-Rojas, M.; Vinicgra-Gonzalez, G.; Favell-Torres, E. Production and properties of three pectinolytic activities produced by Aspergillus niger by submerged and solid state fermentation. Appl. Microbiol. Biotechnol., 43, 803-814, 1995.

2. Acuna-Argulles, M.; Viniergra-Ganzalez, G.; Favela-Torres, E. Effect of water activity on exopectinase production by Aspergillus niger $\mathrm{CH}_{4}$ on solid state fermentation. Biotechnol. Lett., 16, 23-28, 1994.

3. Aguilar, G.; Huitron, C. Stimulation of the production of extracellular pectinolytic activities of Aspergillus species by galacturonic acid and glucose addition. Enzyme Microb. Technol., 9, 690-696, 1987.

4. Aguilar, G.; Trejo, B.; Garcia, J.; Huitron, G. Influence of $\mathrm{pH}$ on endo and exo-pectinase production by Aspergillus species CH-Y-1043. Can. J. Microbiol., 37, 912-917, 1991.
5. Alana, A.; Gabilondo, A.; Hernando, F.; Moragues, M.D.; Dominquez, J.B.; Liama, M.J.; Sessa, J.L. Pectin lyase production by a Penicillium italicum strain. Appl. Environ. Microbiol., 55, 1612-1616, 1989.

6. Baracat-Pereira, M.C.; Coelho, J.L.C.; Silva, D.O. Production of pectin lyase by Penicillium griseoroseum cultured on sucrose and yeast extract for degumming of natural fibers. Lett. Appl. Microbiol., 3, 127-129, 1994.

7. Bartha, J.P.; Cantenys, D.; Touze, A. Purification and characterization of two polygalacturonases secreted by Colletotrichum lindemuthanum. Phytoph. Z., 180, 162-165, 1981.

8. Castilho, L.R.; Alves, L.M.; Medronho, R.A. Recovery of Pectinolytic enzyme produced by solid state culture of Aspergillus niger. Proc. Biochem., 34, 181-186, 1999.

9. Cooney, D.G.; Emerson, R. Thermophilic fungi: An account of their biology, activities and classification. A.H. Freeman and Co. San Fransisco, 1964, 188p.

10. Crotti, L.B.; Terenzi, T.H.F.; Jorge, J.A.; Polizeli, M.L.T.M. Characterization of galactose induced extracellular and intracellular pectolytic activities from the exo-1 mutant strain of Neurospora crassa. J. Ind. Microbiol. Biotech., 20, 238-243, 1998.

11. Fanelli, C.; Cacace, M.G.; Cervone, F. Purification and properties of two polygalacturonases from Trichoderma koningii. J. Gen. Microbiol., 104, 305-309, 1978.

12. Fujio, Y.; Eledago, F.B. Polygalacturonase production by Rhizopus species. J. Gen. Appl. Microbiol., 39, 409-418, 1993.

13. Hang, C.; Dornenburg, H. Perspectives in the biological function and the technological application of polygalacturonases. Appl. Microbiol. Biotechnol., 53, 366-375, 2000.

14. Hart, H.E.; Parish, M.E.; Burns, J.R.; Wicker, L. Orange finisher pulp as substrate for polygalacturonase production by Rhizopus oryzae. J. Food Sci., 56, 480-483, 1991.

15. Loudiere, S.; Durand, A.; Grajek, W. Temprature and $\mathrm{pH}$ influence on pectinolytic activities of some fungi cultured in solid state mebium. J. Eur. Congr-Biotechnol., 3, 258-263, 1987.

16. Lowry, O.H.; Rosenbrough, P.J.; Fass, A.L.; Randall, R.J. Protein Measurement with folin-phenol reagent. J. Biol. Chem., 193, 265$275,1951$.

17. Maheshwari, R.; Bhardwaj, G.; Bhat, M.K. Thermophilic fungi: Their physiology and enzymes. Microbiol. Mol. Bio. Rev., 64, 461-488, 2000.

18. Marciano, P.; Dilenna, P.; Magro, P. Polygalacturonase iso-enzymes produced by Sclerotinia sclerotiorum in vivo and in vitro. Physiol. Plant Pathol., 20, 201-206, 1982.

19. Marcus, L.; Barash, I.; Sneh, B.; Koltin, Y.; Finkler, A. Purification and characterization of pectolytic enzymes produced by virulent and Hypovirulent isolates of Rhizocotonia solaniss. Physiol. Mol. Plant Pathol., 29, 325-336, 1986.

20. Minjares-Cassanco, A.; Trejor-Aguillas, B.A.; Aguilar, G. Physiological comparison between pectinase producing mutants of Aspergillus niger adopted either to solid state fermentation or submerged fermentation. Enzyme Microb. Technol., 21, 26-27, 1997.

21. Minussi, R.C.; Coelho, J.L.C.; Baracat-Pereira, C.M.; Silva, D.O. Pectin lyase production by Penicillium griseoroseum: Effect of tea extract, caffeine, yeast extract and pectin. Biotechnol. Lett., 18, 1283-1286, 1996.

22. Rubinder, K.; Chadha, B.S.; Singh, N.; Singh, S.; Saini, H.S. Amylase hyper production by deregulated mutants of the thermophilic fungus Thermomyces lanuginosus. J. Ind. Microbiol. Biotechnol., 29, 7074, 2002.

23. Rubinder, K.; Chadha, B.S.; Singh, S; Saini, H.S. Amylase hyper producing haploid recombinant strains of Thermomyces lanuginosus obtained by intraspecific protoplast fusion. Can. J. Microbiol., 46:669-673, 2000 
Pectinase and polygalacturonase production by A. fumigatus

24. Said, S.; Fonseca, M.J.V.; Siersera, V. Pectinase production by Pencillium frequentans. World J. Microbiol. Biotechnol., 7, 607-608, 1991.

25. Sapunova, L.I. Pectinohydrolases from Aspergillus alliaceus Biosynthesis characteristic features and applications. Cand. Sci. (Biol.) 1990, Dissertation, Minsk: Institute of Microbiology Belarussian Academy of Science.

26. Sapunova, L.I.; Lobanok, G.; Mickhailova, R.V. Conditions of synthesis of pectinases and proteases by Aspergillus alliaceus and production of a complex macerating preparation. Appl. Biotechnol. Microbiol., 33, 257-260, 1997.
27. Singh, S.; Sandhu, D.K. Thermophilous fungi in Port Blair soils Canadian J. Bot., 64, 1018-1026, 1986.

28. Spanga, G.; Pefferi, P.G.; Gillali, E. Immobilization of a pectin lyase from Aspergillus niger for Application in food technology. Enzyme Microb. Technol., 17, 729-738, 1995.

29. Taragano, V.; Sachez, V.E.; Pilosof, A.M.R. Combined effect of water activity depression and glucose addition on pectinases and pectinase production by Aspergillus niger. Biotechnol., Lett. 19, 233-236, 1997. 